\title{
Digestibility of Proteins
}

Trials on animals and human subjects have shown that the proteins as contained in wholemeal are less well utilized than those in white flour. Macrae and his 5 volunteers (Macrae, Hutchinson, Irwin, Bacon and McDougal, 1942) found the average coefficients of apparent digestibility of the nitrogen in bread made from flours of 100 per cent. and 73 per cent. extraction to be, respectively, 85.5 and 91 . In the case of the rats, whose performance is summarized in Table 2 , the respective average coefficients were $82 \cdot 4$ and $87 \cdot 3$. This loss of about 6 per cent. in digestibility was, however, more than compensated by the greater nutritive value of the proteins of the wholemeal flour.

\section{REFERENCES}

Boas-Fixsen, M. A. (1935). Nutr. Abstr. Rev. 4, 447.

Chick, H. (1942). Lancet, 242, 405.

Girard, A. (1884). Ann. Chim. (Phys.) S'ér. VI, 3, 289.

Hove, E. L. and Harrel, C. G. (1943). Cereal Chem. 20, 141.

Jones, D. B. and Gersdorff, C. E. F. (1923). J. biol. Chem. 58, 117.

Jones, D. B. and Gersdorff, C. E. F. (1926). J. biol. Chem. 64, 241.

Macrae, T. F., Hutchinson, J. C. D., Irwin, J. O.,"Bacon, J. S. D. and McDougall, E. I. (1942). J. Hyg., Camb., 42, 423.

MoCollum, E. V., Orent-Keiles, E. and Day, H. G. (1939). The Newer Knowledge of Nutrition, 5th ed., Appendix. New York: The Macmillan Co.

Mitchell, H. H. (1924). J. biol. Chem. 58, 873.

Mitchell, H. H., Hamilton, T. S. and Shields, J. B. (1943). J. Nutrit. 25, 585.

Osborne, T. B. and Mendel, L. B. (1919). J. biol. Chem. 37, 557.

Osborne, T. B., Mendel, L. B. and Ferry, E. L. (1919). J. biol. Chem. 37, 223.

Osborne, T. B. and Vorhees, C. G. (1893). Amer. Chem. J. 15, 392.

Wright, M. D. (1941). Brit. Med. J. ii, 689.

\section{Vitamin Values of Different Types of Flour}

\author{
Miss A. M. Copping (Division of Nutrition, Lister Institute, \\ London, S.W.1)
}

\section{Carotenoids}

From the standpoint of vitamin nutrition the main importance of the wheat grain lies in its content of the $\mathbf{B}$ vitamins. The biologically active carotenoids of wheat constitute only a small part of the total pigments present in the grain. Early colorimetric estimations had appeared to indicate a fairly high carotene content in some varieties of wheat but later colorimetric and biological tests have not shown similar results. The carotene appears to be evenly distributed in the different parts of the grain, since biological tests with rats have indicated that the animals survive for approximately the same length of time when unbleached white flour of 73 per cent. extraction or wholemeal flour of 92 per cent. extraction from the same grist is the sole source of vitamin $\mathrm{A}$ in the diet (Hume, unpublished work).

\section{Vitamin $E$}

The germ of the wheat grain is one of the richest natural sources of vitamin $\mathrm{E}$ (tocopherol) and was the form of the vitamin most generally used until synthetic tocopherols became available. By means of a chemical method of estimating tocopherols with a ferric chloride reagent, vor. 4,1946$]$ 
Engel (1942) made a study of the distribution of vitamin $\mathrm{E}$ in the wheat grain. The concentrations in $\mathrm{mg}$. per $100 \mathrm{~g}$. were 1.7 in white flour of 70 per cent. extraction, 5.9 in flours of 82 to 90 and of 90 to 100 per cent. extraction, and 27 in wheat germ. Thus, increase in extraction above about 80 per cent. provides a valuable increase in the vitamin $E$ content of the flour.

\section{The Vitamin $B$ Complex}

There is now available a considerable amount of information on the distribution of the members of the vitamin B complex, particularly vitamin $B_{1}$ and riboflavin, in the wheat grain. Many useful papers on American and Canadian wheats have appeared in Cereal Chemistry in the last three years and, although it is impossible in a brief survey such as this to cover the field adequately, mention should be made of the reports of Jackson and Whiteside (1942) and of Whiteside and Jackson (1943) who studied a great number of samples of Canadian wheat of different varieties from different provinces. Estimation of vitamin $B_{1}$ by a modification of the thiochrome method gave values with an extreme range of 2.8 to $8.5 \mu \mathrm{g}$. per g. whole wheat, though in the 1942 study most samples gave values close to a median of $4 \cdot 3 \mu \mathrm{g}$. per $\mathrm{g}$. It was observed that hard wheats had a consistently higher vitamin $B_{1}$ potency than soft wheats, and that the varieties of hard wheat known as Regent, Reward and Renown had always a higher content of vitamin $\mathrm{B}_{1}$ than the varieties Apex, Thatcher and Marquis. This result was maintained in the crops over the two seasons and in wheats grown in different localities; it presents the possibility of breeding strains of wheat rich in vitamin $B_{1}$ and probably in other nutritive constituents, and of improving the vitamin content of flours by including high vitamin wheats in the grist.

Another useful report is that of Jackson, Doherty and Malone (1943), who estimated vitamin $B_{1}$ by the thiochrome method, and riboflavin and nicotinic acid by microbiological methods in all fractions of the mill stream of a large Canadian flour mill. They found the highest proportion of vitamin $B_{1}$ in the shorts fraction and large amounts of riboflavin in the shorts, bran and first patent flour; nearly half the nicotinic acid was in the bran. When the wheat grain was investigated by dissection, 59 per cent. of the vitamin $B_{1}$ was found in the scutellum while riboflavin appeared to be more evenly distributed as shown by the relatively large amounts present in the flours. This observation has not been substantiated by other observers as will be seen later. Nicotinic acid was present chiefly in the outer branny layers. These findings found application in the milling of the high vitamin white flour known as Canada Approved which has a vitamin $B_{1}$ content of $2 \cdot 4$ to $2 \cdot 65 \mu \mathrm{g}$. per $\mathrm{g}$.

Dissection of the wheat grain has been made also in this country and extensive studies are reported by Hinton $(1942,1944)$ and by Ward (1943). The former found that the scutellum portion of the germ formed about 1.5 per cent., and the embryo proper consisting of the plumule and radicle about 1.2 per cent., of the total weight of the wheat grain. The embryo was hard and the scutellum soft and powdery but firmly attached to the grain. In dry-milled wheat the portion of the germ which was removed in milling contained little of the scutellum which passed into the flour and therefore increased the vitamin $B_{1}$ content of the flour. With wheat conditioned to contain 16 to 17 per cent. moisture 
the whole germ was removed in the milling. In commercial specimens of wheat germ it was found that the fractions containing the large particles of pure embryo and possessing a high protein content were less rich in vitamin $B_{1}$ than fractions with the smallest sized particles of lower protein content which contained the powdery scutellum. It. was estimated that the embryo contained about 3 , and the scutellum about 59 , per cent. of the total vitamin $B_{1}$ present in the grain. From a number of different wheats, values ranging from 41 to 75 I.U. per g. were found for the scutellum. Hinton (1942) found the riboflavin content of commercial wheat germ to be 9 to $12 \mu \mathrm{g}$. per g. with no evidence of an increased concentration of this factor in the scutellum. The nicotinic acid content of wheat germ was about $60 \mu \mathrm{g}$. per g. The high vitamin $\mathrm{B}_{1}$ content of the scutellum indicated the possibility of milling a flour with a high vitamin content if this portion of the germ was specially included.

In 1940 when it became obvious that this country would have to face its food problems very seriously, the Medical Research Council began to consider the special problems of the nation's bread and flour in order to obtain the highest possible nutritive value from the available wheat. The result of their deliberations and practical tests was submitted in a memorandum (Medical. Research Council, 1941), which specified that in National wheatmeal there should be present 85 per cent. of the weight of the cleaned wheat, or in the case of a reconstituted flour there should be all the white flour, all the reduction roll tails, mill finish and purifier tails, and sufficient fine bran to bring the meal to the 85 per cent. extraction rate. According to this specification the National wheatmeal should contain not less than 1 I.U. vitamin $B_{1}$ per $g$. and its fibre content should not exceed 0.9 per cent.

In the course of preliminary investigations on the National wheatmeal, estimations of the vitamins of the B complex were undertaken by the Division of Nutrition of the Lister Institute, on flours and offals milled from the same grist. The figures given in Table 1 were obtained by

TABLE 1

The Vitamin $B_{1}$, Riboflavin and Vitamin $B_{6}$ Content of Flours of Different Degregs of Extraction and of Offals, Determined Biologrcally WITH Rats

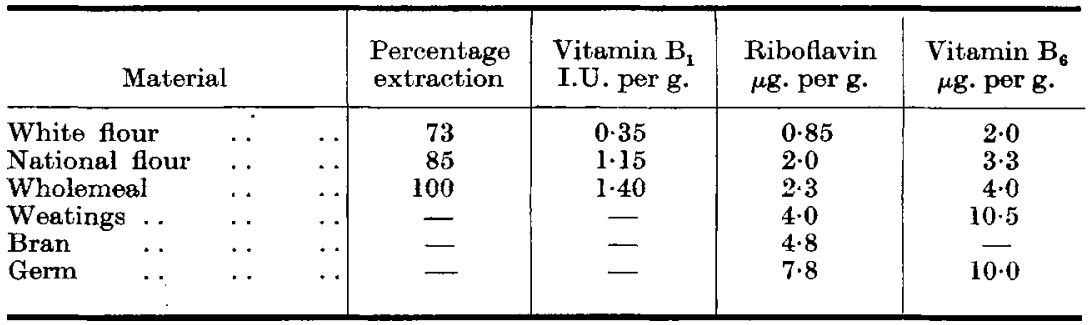

biological methods with weight inorease of young rats as criterion (Copping, 1943). The flours were milled in January, 1941, except for the 85 per cent. extraction flour which was milled in June, 1941, from stored grist, after the specification for National wheatmeal had been set out. The values for vitamin $B_{1}$, riboflavin and vitamin $B_{6}$ show that the vox. 4, 1946] 
85 per cent. extraction flour is a good source of all these factors and, with respect to water soluble vitamins, much superior in nutritive value to white flour of 73 per cent. extraction which was at that time the flour in general use for breadmaking. The other members of the vitamin B complex were estimated as a group, with a sam ple of yeast as standard. The figures are not included in the table owing to the difficulty of expressing the results simply. It is, however, clear from the experiments that 85 per cent. extraction flour contained more than 70 per cent. of these vitamin B factors present in whole wheat while 73 per cent. extraction flour contained only about 40 per cent. The concentration of these other $B$ vitamins in the weatings and germ was nearly twice that in the whole grain.

Microbiological estimations of riboflavin were made on these samples of flours by Dr. Davis and Mr. Newland at the National Institute for Research in Dairying, Shinfield, and on similar but not identical samples by Dr. Barton-Wright at the Cereals Research Station, St. Albans. The results of all these estimations are collected together in Table 2 and show remarkably good agreement.

TABLE 2

Riborlavin Content of Various Cereal Products Determ ined Brologically WITH RATS, AND MiCRoBIOLOGICALLY

\begin{tabular}{|c|c|c|c|c|}
\hline \multirow[b]{2}{*}{ Material } & \multirow[b]{2}{*}{$\begin{array}{l}\text { Percentage } \\
\text { extraction }\end{array}$} & \multicolumn{3}{|c|}{ Riboflavin content, $\mu \mathrm{g}$. per g. } \\
\hline & & $\begin{array}{l}\text { Determined } \\
\text { biologically }\end{array}$ & $\begin{array}{c}\text { Determined } \\
\text { microbiologically } \\
\text { on same samples }\end{array}$ & $\begin{array}{l}\text { Determined } \\
\text { microbiologically } \\
\text { on similar samples }\end{array}$ \\
\hline White flour & 73 & $0 \cdot 85$ & $0 \cdot 83$ & 0.75 to 1.25 \\
\hline National Hour... & 85 & $2 \cdot 0$ & $2 \cdot 14$ & $2 \cdot 00$ to $2 \cdot 10$ \\
\hline Wholemeal & 100 & $2 \cdot 3$ & $2 \cdot 78$ & 2.65 to $3 \cdot 70$ \\
\hline Weatings & - & $4 \cdot 0$ & $5 \cdot 9$ & - \\
\hline Bran . & $\ldots$ & $4 \cdot 8$ & - & 5 to 8 \\
\hline Germ $\quad \ldots$ & - & $7 \cdot 8$ and $12 \cdot 0$ & - & $9 \cdot 7$ to $12 \cdot 8$ \\
\hline
\end{tabular}

These figures are the more interesting if one takes the values published in successive reports from the Cereals Research Station on the composition of National flour and bread (Research Association of British Flour-Millers,

TABLE 3

Changes in the Vitamin Content of National Flour between 1942 AND 1944

\begin{tabular}{c|c|c|c|c}
\hline Date & $\begin{array}{c}\text { Percentage } \\
\text { extraction }\end{array}$ & $\begin{array}{c}\text { Vitamin B } \\
\text { I.U. per g. }\end{array}$ & $\begin{array}{c}\text { Riboflavin } \\
\mu \text { g. per g. }\end{array}$ & $\begin{array}{c}\text { Nicotinic acid } \\
\mu \text { g. per g. }\end{array}$ \\
\cline { 2 - 4 } 1942 & 85 & $1 \cdot 10$ & $1 \cdot 7$ & - \\
1943 & 85 & $1 \cdot 00$ & $1 \cdot 5$ & - \\
1944 & 85 & 0.975 & $1 \cdot 3$ & 17 \\
1944 & $82 \frac{1}{2}$ & 0.88 & $1 \cdot 0$ & 18 \\
\hline
\end{tabular}

1942; Ministry of Food, Scientific Adviser's Division, 1942, 1943, 1944, $1,2,3$ ). From Table 3 it will be seen that there has been a steady decrease 
in the vitamin $B_{1}$ and riboflavin content of National flour since 1942 when a small amount of imported white flour was first added. This flour, Canada G.R., had a reasonably high vitamin $B_{1}$ content and its presence tended to lower the fibre content of the National wheatmeal but unfortunately lowered also the riboflavin content. The fall in vitamin $B_{1}$ content of the National flour was partly due to an increase in the percentage of home grown wheat in the grist and to a lower content of bran in the flour. When barley, oats or rye was added these grains were milled to an extraction which would have no significant effect on the fibre and vitamin $B_{1}$ content of the finished flour. The fall in riboflavin content is particularly marked and it is important to notice that in the change on October lst, 1944, to flour of $82 \frac{1}{2}$ per cent. extraction there was a further loss of nearly 25 per cent. of this factor as compared with values obtained from flour samples of 85 per cent. extraction taken earlier in 1944. Actually with this new extraction the riboflavin value has been lowered to balf the value found for the original samples of 85 per cent. extraction flour milled in 1941. This result may be partly accounted for by the inherent difficulties in the accurate estimation of the riboflavin content of cereal products as pointed out by Andrews (1943) in his report on methods of analysis. It is possible also that changes in the types of wheat composing the grist would alter the riboflavin content of the finished flour. Since there are such marked variations in the vitamin $B_{1}$ and other constituents of different varieties of wheat it is more than probable that similar variations occur in the riboflavin content, though no extensive figures are at present available.

A recent Ministry of Food (1944) pamphlet on "High Vitamin Flour" is concerned with the milling problems involved in obtaining an $82 \frac{1}{2}$ per cent. extraction flour of optimum nutritive value. It is stressed that the first essential is still to include all the germ and especially the scutellum. This is the practical application of the researches on the germ described earlier in this paper. The inclusion of the scutellum will assure the continued high potency in vitamin $B_{1}$ of the National flour but does not make certain that the riboflavin value is maintained and one would like to know that this important dietary factor is being preserved in an article of diet as widely used as flour.

\section{References}

Andrews, J. S. (1943). Cereal Chem. 20, 613.

Copping, A. M. (1943). Biochem. J. 37, 12.

Engel, C. (1942). Z. Vitaminforsch. 12, 220.

Hinton, J. J. C. (1942). J. Soc. Chem. Ind. 61, 143.

Hinton, J. J. C. (1944). Biochem. J. 38, 214.

Jackson, S. H., Doherty, A. and Malone, V. (1943). Cereal Chem. $20,551$.

Jackson, S. H. and Whiteside, A. G. O. (1942). Sci. Agric. 22, 366.

Medical Research Council (1941), Brit. Med. J. i, 828.

Ministry of Food (1944). High. Vitamin Flour. Cereals Research Station, St. Albans.

Ministry of Food. Scientific Adviser's Division (1942). Nature, Lond, 150, 538. Ministry of Food. Scientific Adviser's Division (1943). Nature, Lond., 151, 629. Ministry of Food. Scientific Adviser's Division $(1944,1)$. Nature, Lond., 153, 154. Ministry of Food. Scientific Adviser's Division (1944, 2). Nature, Lond., 154, 582. Ministry of Food. Scientific Adviser's Division (1944,3). Nature, Lond., 154, 788. Research Association of British Flour-Millers (1942). Nature, Lond., 149, 460.

Ward, A. H. (1943). Chem. and Ind. 62, 11 .

Whiteside, A. G. O. and Jackson, S. H. (1943). Cereal Chem. 20, 542.

voL. 4, 1946] 